Метлицька О. І., кандидат сільськогосподарських наук

Інститут свинарства та агропромислового виробництва НААНУ

Копилова К. В., кандидат сільськогосподарських наук

Інститут розведення і генетики тварин НААНУ

\title{
ПОЛІМОРФІЗМ МІТОХОНДРІАЛЬНОЇ ДНК ДЛЯ ОЦІНКИ ГЕНЕТИЧНОЇ СТРУКТУРИ І ПІДВИДОВОЇ КЛАСИФІКАЦІЇ УКРАЇНСЬКИХ БДЖІЛ
}

\author{
Рецензент - доктор сільськогоспродарських наук Б. С. Подоба
}

\begin{abstract}
Визначене спільне еволюиійне походження украӥнської, карпатської і кавказької бджіл за СОI-СОII локусом мтДНК, що дозволяє віднести названі підвиди до середземноморської гілки С. Наявність у популяціях українських бджіл лише мітохондріального гаплотипу $Q$ свідчить про відсутність помісних сімей, метизованих бджолами середньоросійської породи. Безпідставність застарілих уявлень щьодо украӥнських бджіл як екотипу темної європейської бджоли під назвою Apis mellifera асегvотит вимагає перегляду їх таксономічної класифікації, згідно запропонованої M. Engel Apis mellifera sossimai. Встановлений відносний консерватизм міжгенної ділянки СОІ-СОІІ иляхом рестриктного аналізу може бути зумовлений функціональною важливістю даного генетичного локусу.
\end{abstract}

Ключові слова: мітохондріальна ДНК, локус, поліморфізм, рестриктаза, ампліфікаиія, популячія, генофонд.

Постановка проблеми. Морфометричні дослідження традиційно становлять основу дослідження еволюційної історії, філогенетичних взаємин, особливостей міграції різних видів і підвидів (рас) бджоли медоносної (Apis mellifera L), широко розповсюдженій в усіх частинах світу від Європи до Азії та Африки завдяки унікальним адаптаційним властивостям. Перші критерії для внутрівидової систематики Apis mellifera були створені В. В. Алпатовим, але загальна морфометрична європейська система набула довершеного вигляду лише після внесення в неї значних коректив F. Ruttner [10]. До останнього часу в бджільництві для оцінки ступеня генетичних особливостей підвидів (чистопородності) використовували переважно морфофізіологічні критерії: забарвлення тіла, довжину хобітка, особливості жилкування крил, кубітальний індекс, яйценосність маток та ін., тобто показники, що значною мірою підлягають дії абіотичних і природних факторів, у тому числі й антропогенному тиску. Тому визначення породності основи гібридних популяцій, що виникають внаслідок ін- тродукції до аборигенних масивів бджіл невідомого походження, на основі оцінки певних частин екзоскелету встановити не вдається з причин значного варіювання ознак як результат визначних рекомбінаційних подій [5].

У вирішенні важливих питань встановлення породної (підвидової або расової) належності бджіл, збереження їх унікального генофонду в межах природних ареалів постала нагальна проблема пошуку молекулярно-генетичних методів, що грунтуються на визначенні характеристик безпосередньо носіїв спадковості - ДНК маркерів. Однією $з$ найбільш привабливих маркерних систем для визначення особливостей генетичного поліморфізму бджіл на внутрівидовому рівні $\epsilon$ дослідження локусів ДНК мітохондрій (мтДНК) [12], що не підлеглі впливу факторів зовнішнього середовища. Використання саме цих маркерів має низку переваг, які грунтуються на особливостях спадкування та організації мітохондріального геному.

Аналіз основних досліджень і публікацій, у яких започатковано розв'язання проблеми. Особливістю мтДНК як молекулярного маркера $\epsilon$ успадкування лише від одного 3 батьків: вона передається за материнською лінією (від матері до нащадків) у процесі запліднення. Внаслідок материнського спадкування в мітохондріальному геномі відсутні генетичні рекомбінації, - таким чином успадковується єдиний гаплотип набір тісно зчеплених локусів. Мутаційний процес виступає в якості єдиного чинника у формуванні поліморфізму мтДНК, а мутації, що зберігаються і накопичуються в мітохондріальному геномі, можуть бути відбитком еволюційної історії виду чи окремої особини.

У всіх еукаріотичних організмів, у тому числі й бджоли медоносної, мтДНК виконує однакові функції: кодує обмежену кількість молекул РНК і білків, необхідних для існування мітохондрій. Встановлено, що мітохондрії, як важливі органели еукаріотичних клітин, виконують функції 
тканинного дихання і синтез АТФ, проте в мускулатурі комах їх роль обмежується виключно виробленням енергіï [11].

Проведення повного секвенційного аналізу мтДНК бджоли медоносної показало, що ДНК мітохондріону має кільцеву структуру довжиною 16343 п. н., а нуклеотидний склад мтДНК демонструє надзвичайну кількість АТ кодонів (84,9 \%, порівняно з 78,6 \% у дрозофіли). Ділянки мтДНК, які кодують білки, є високо консервативними, проте для структури тРНК і некодуючого регіону відзначена висока норма мутаційних подій, що перевищує аналогічну для ядерних ділянок ДНК у 10-20 разів $[12,5]$.

Невеликий розмір та висока концентрація мітохондріонів у клітинах тварин значно полегшує дослідження поліморфізму цієї органели, даючи змогу ефективно досліджувати різноманітність їі генофонду. Нині структуру мітохондріального геному активно використовують для дослідження еволюційних зв'язків і визначення підвидової (породної) належності бджоли медоносної та інших тварин [2].

Перші дослідження мінливості мтДНК бджіл довели точність морфометричних критеріїв Ruttner для оцінки філогенетичних взаємин [7] i показали існування трьох еволюційних гілок походження бджоли медоносної А М і С.

На основі мітотипів, отриманих шляхом рестрикції міжгенної ділянки СОI-COII мтДНК та секвенування гена 2 субодиниці NADH P. Franck et al. провели уточнення межі між еволюційними гілками, їх склад та історію походження підвидів. У результаті цих досліджень доведено існування чотирьох еволюційних гілок Apis mellifera на морфометричному і молекулярному рівнях $[4,6]$.

Найрозповсюдженішим генетичним тестом, призначеним для встановлення диференціації між підвидами (породами) бджіл, є аналіз маркерної ділянки мітохондріального геному Apis mellifera - АТ насичений міжгенний локус, розташований між генами субодиниць цитохром оксидази I i II (COI-COII), що складається зі змінної кількості двох основних послідовностей P/Po i Q [6]. Згідно $з$ даною методикою, за використання запропонованої пари праймерів Е2 та Н2, можна отримати амплікони, що значно відрізняються за молекулярною масою у бджіл різного еволюційного походження. Так, для бджіл африканського походження лінії А можна отримати фрагменти 638-830 п.н. (у бджіл $A . m$. major та A. m. intermissa відповідно), бджоли лініï М характеризуються високомолекулярним гаплотипом розміром 825-1021 п. н. (підвиди
A. m. iberica різних екотипів), особини гілки С надають можливість отримати ДНК-фрагменти розміром 571-572 п. н. (A. m. caucasica, $A$. $m$. carnica) внаслідок утворення значної делеції в ділянці Р. Саме послідовність Р дає можливість розрізнити бджіл різного мітохондріального походження - вона відсутня у бджіл лінії $\mathrm{C}$, містить 54-56 п. н. в гілці М (послідовність Р) і 6269 п. н. у бджіл еволюційної гілки А (послідовність Ро). С гаплотипи містять ліше один ДНКфрагмент Q, тоді як особини А і М гаплотипів можуть мати до чотирьох $Q$ послідовностей. Окрім цього, визначається поліморфізм даного міжгенного локусу за допомогою DraI фермента рестрикції, переважно для підвидів ліній А і M, що призводить до утворення більше ніж 50 гаплотипів [8].

Запропонований метод набув значної популярності для вирішення породної належності бджіл, особливо в регіонах, де проходять межі розповсюдження представників різних еволюційних гілок, а також для визначення чистопородних резерватів аборигенних бджіл із метою збереження їх унікальних генофондів із високою адаптивною здатністю до місцевих географічних та екологічних умов.

Мета дослідження. Метою даного дослідження є генетичний моніторинг наявних генофондів українських аборигенних бджіл за поліморфізмом міжгенного локусу COI-COII мтДНК для встановлення ступеня їх метизації представниками інших рас (карпатська та сіра гірська кавказька) й уточнення підвидової класифікації українських степових бджіл.

Матеріали і методика досліджень. Проводили відбір імаго робочих бджіл у кількості по 10 особин - представників різних сімей: українська порода - плембджолорозплідник «Прибузькі медобори», с. Головчинці Летичівського району Хмельницької області та приватна пасіка Сгошина Л. Р. (с. Куземин Охтирського району Сумської області); карпатська порода - ПП Яценко В. В. (с. Дрозди Білоцерковського району Київської області), плембджолорозплідник «Вучківський» (с. Вучкове Міжгірського району Закарпатської області); сіра гірська кавказька бджолорозплідник «Червона Поляна» (Грузія). Проби зберігали у 70 \%-му розчині етанолу. Виділення ДНК проводили сорбентним методом із застосуванням комерційного набору «ДНК-Сорб В» («Амплісенс», Росія, Москва) у власній модифікації. Після розтирання комах у скляному гомогенізаторі (для видалення воску з проб із метою запобігання потрапляння інгібіторів у реакційну 
ПЛР-суміш) у кожний зразок додавали 1000 мкл октану і проводили інкубацію при $90{ }^{\circ} \mathrm{C}$ протягом 5 хвилин, центрифугували при 8000 об./хв протягом 5 хвилин. Супернатант видаляли одноразовими піпетками, а осад підсушували за кімнатної температури й використовували для виділення ДНК. Внаслідок проведеної оптимізації методики отримана ДНК, придатна для поповнення банку довготривалого збереження.

Ампліфікацію міжгенної ділянки цитохром оксидази мтДНК бджоли медоносної та її рестрикцію ферментом Dra I виконували згідно з методичними рекомендаціями [8]. Для рестрикції міжгенної ділянки COI-COII використовували додатково рестриктазу Bsu RI (HaeIII), Alu I i Tas-I, ферментативну реакцію проводили за рекомендаціями виробника («Fermentas», Литва). Електрофоретичне розділення фрагментів ампліфікації та рестрикції проводили в камері для вертикального електрофорезу на 7 \%-их поліакриламідних гелях в однократному ТВЕ буфері [3]. Забарвлення гелів виконували за допомогою розчину бромистого етидію, гелі оглядали після багаторазової відмивки бідистильованою водою під УФ-світлом на трансілюмінаторі, фотодокументацію проводили за допомогою цифрового апарата «Canon».

Результати досліджень. Внаслідок виконаних реакцій ампліфікації міжгенної ділянки COICOII мтДНК отримано продукти однакової молекулярної маси для всіх проаналізованих представників різних порід розміром 572 п. н. Контроль розмірів продуктів рестрикції ампліфікованих фрагментів COI-COII мтДНК бджіл був проведений у відповідності з нуклеотидною послідовністю, отриманою внаслідок секвенування для представників підвиду Apis mellifera ligustica (за даними GenBank [9]), що відноситься до фiлогенетичної гілки походження $\mathrm{C}$ і має подібну структуру у бджіл порід карніка та сіра гірська кавказька за винятком лише двох однонуклеотидних замін, що не $є$ сайтами впізнавання рестриктази Dra I.

Згідно з нуклеотидною послідовністю COICOІІ мтДНК, для всіх проаналізованих бджіл представників трьох порід - був виявлений однаковий спектр фрагментів рестрикції з розмірами 47, 40, 63 та 421 п. н. Результати гаплотипування бджіл різних порід і популяцій та кількість обстежених сімей наведені в таблиці.

У результаті проведеного аналізу представники всіх досліджених сімей трьох порід мали однаковий мітохондріальний гаплотип - $\mathrm{Q}$, характерний для бджіл південних порід філогенетичної гілки С. Таким чином, аналіз поліморфізму міжгенної ділянки мтДНК COI-COII за використання рестриктази Dra I не дає змоги віддеференціювати представників трьох порід і визначити гібридні сім’ї української породи бджіл із представниками карпатської та кавказької. Проте можна однозначно стверджувати, що досліджені популяції українських бджіл вільні від метизації тваринами середньоросійської породи, для яких характерна висока частота мітохондріальних гаплотипів PQ та PQQ. Наявність мтДНК гаплотипу, властивого особинам підвиду Apis mellifera mellifera (середньоросійська або темна європейська порода бджіл), згідно зі встановленою нуклеотидною послідовністю міжгенної ділянки цитохром оксидази (дані GenBank), може бути виявлена вже на етапі отримання фрагменту ампліфікації, який для бджіл середньоросійської породи має бути найчастіше на рівні 629 п. н. (гаплотип PQ) або 825 п. н. ( PQQ).

Таким чином, результати проведеного дослідження підтверджують, що українська порода бджіл не є південною гілкою середньоросійської породи, в досліджених популяціях української степової не виявлено помісних сімей із представниками Apis mellifera mellifera, а існуюча

Частота алелей поліморфного локусу СОІ-СОІІ мтДНК бджіл трьох порід

\begin{tabular}{|c|c|c|c|}
\hline Популяції & Кількість сімей & Частота Q & Частота PQ \\
\hline $\begin{array}{c}\text { Українська степова, } \\
\text { Хмельницький тип }\end{array}$ & 10 & 1,00 & 0,00 \\
\hline $\begin{array}{c}\text { Українська степова, } \\
\text { Новоукраїнський тип }\end{array}$ & 10 & 1,00 & 0,00 \\
\hline $\begin{array}{c}\text { Карпатська, } \\
\text { Київська обл. }\end{array}$ & 10 & 1,00 & 0,00 \\
\hline $\begin{array}{c}\text { Карпатська, } \\
\text { тип Вучківський }\end{array}$ & 10 & 1,00 & 0,00 \\
\hline $\begin{array}{c}\text { Сіра гірська кавказька, } \\
\text { Грузія }\end{array}$ & 10 & 1,00 & 0,00 \\
\hline
\end{tabular}


застаріла підвидова класифікація українських степових бджіл Apis mellifera acervorum Scor. дійсно потребує перегляду у відповідності 3 інформацією, отриманою на молекулярногенетичному рівні.

Iз метою пошуку додаткових однонуклеотидних замін у ділянці COI -COII у представників трьох вищезазначених порід бджіл для їх молекулярно-генетичної ідентифікації були використані додаткові ферменти рестрикції.

Відповідно до нуклеотидної послідовності міжгенної ділянки цитохром оксидази бджіл італійської породи (лігустіка), для ендонуклеаз Нае III та Alu I сайтів впізнавання не знайдено. Проведення реакцій рестрикції ампліфікованих фрагментів COI-COII у представників трьох порід бджіл (по 10 особин різних сімей від кожної) 3 ферментами Hae III та Alu I не дало можливості виявити однонуклеотидні заміни в цій ділянці мітохондріальної ДНК. Щільноподрібнююча рестриктаза Tas I дала можливість встановити надто широкий спектр сайтів впізнавання в межах цього фрагмента мтДНК. Діапазон молекулярних мас рестриктів коливався від 4 п. н. до 60 п. н., що вимагав застосування лише поліакриламідних гелів високої концентрації акриламіду (не менше 8 \%). Згідно 3 проведеним ПЛР-ПДРФ аналізом iз ферментом Tas I мт ДНК вибірки бджіл різних сімей представників трьох порід (по 10 особин від кожної породи) отриманий спектр фрагментів рестрикціі, що відповідав теоретично розрахованому, відповідно до генетичної карти міжгенного фрагмента COI-COII A. m. ligustica. Додаткових сайтів впізнавання для ендонуклеази Tas I, які виникли внаслідок однонуклеотидних замін або інших мутацій ув міжгенній ділянці цитохром оксидази мтДНК виявити не вдалося. Очевидно, що встановлення однонуклеотидних замін на міжгенній ділянці COI-COII мтДНК є проблематичним внаслідок методичних обмежень рестриктного аналізу 3 наступним розділенням фрагментів шляхом електрофорезу. Таким чином, виявлення поліморфізму мтДНК із метою ідентифікації бджіл досліджуваних порід та виявлення гібридних

\section{БІБЛІОГРАФІЯ}

1. Ильясов P. A. Филогенетика подвидов Apis mellifera / Р. А. Ильясов, А. В. Поскряков // Пчеловодство. - 2006. - №7. - С. 18-19.

2. Кривцов Н. И. Породообразовательный процесс в пчеловодстве / Н. И. Кривцов, А. В. Бородачев // Пчеловодство. - 2008. - №6. - С. 10-13. 3. Маниатис T. Молекулярное клонирование / сімей можливо лише за умов використання сучасного обладнання - секвенатора, що дозволяє встановлення і порівняння повних нуклеотидних структур будь-яких ділянок ДНК. Для проведення наступних досліджень у цьому напрямі доцільно залучити інші, більш еволюційні пластичні ділянки мітохондріону бджоли медоносної. Виконана робота $є$ першою спробою щодо оцінки наявних генофондів аборигенних бджіл із метою встановлення природних чистопородних резерватів, їх збереження та вдосконалення.

Висновки. Встановлено, що районовані в Україні породи бджіл - українська та карпатська, а поряд із ними - сіра гірська кавказька, що найчастіше інтродукується у популяції місцевої бджоли, згідно зі встановленими гаплотипами мтДНК відносяться до еволюційної гілки С, тобто мають єдину предкову форму середземноморського походження. Відсутність у проаналізованих популяціях української степової бджоли особин із Р гаплотипом мтДНК може однозначно свідчити про відсутність гібридних сімей із тваринами середньоросійської породи (Apis mellifera mellifera, або темна європейська бджола), а також про безпідставність наукових гіпотез щодо українських бджіл як південне відгалудження цього підвиду. Тому застарілу підвидову класифікацію Apis mellifera acevorum Scor. варто замінити на запропоновану М. Engel Apis mellifera sosimai Engel. Визначений нами відносний консерватизм обраної ділянки мтДНК може бути пов'язаний із заниженою швидкістю мутаційних подій, викликаних важливою функціональною особливістю цієї нуклеотидної послідовності. Даний ДНК-фрагмент може певним чином впливати на активність цитохром оксидази, i тому суттєві порушення цієї структури виявляються не адаптивним для виду в цілому й відсікаються природним добором. Відсутність суттєвої різниці в генетичній структурі локусу COI-COII у представників різних проаналізованих порід лише підтверджує їх спільне еволюційне походження, не тривалий час їх дивергенції та відносно незначну географічну ізоляцію.

Т. Маниатис, Э. Фрич, Д. Сэмбрук // Пер. с англ., под ред. А. А. Баева. - М. : Мир, 1984. - 479 с.

4. Arias M. C., Sheppard W.S. Molecular phylogenetics of honeybee subspecies (Apis mellifera L.) inferred from mitochondrial DNA sequence // Mol. Phyl. Evol. - 1996. - V. 5. P. 557-566. 
5. Bouga M., Alaux C., Bienkowska M. et. al. A review of methods for discrimination of honey bee populations as applied to European beekeeping // Journal of Apicultural Research. - 2011. - V. 50. №1. - P. 51-84.

6. Franck P., Cornuet J.-M., Solignac M., et.al. Honeybee phylogeography in Europe: new insights from the analysis of Italian honeybees with microsatellite and mitochondrial markers // Social Insects at the Turn of the Century, Proc. XIII Int. Congr. IUSSI, Flinders Univ. Press, Adelaide, Australia, 1999. - P. 170.

7. Garnery L., Cornuet J.-M., Solignac M., Evolutionary history of the honeybee Apis mellifera inferred from mitochondrial DNA analysis // Mol. Ecol. - 1992. - V. 1. - P. 145-154.
8. Gernary L., Solignac M., Celebrano G. et al. A simple test using restricted PCR-amplification mitochondrial DNA to stady the genetic structure of Apis mellifera L. // Experientia. - 1993. - V. 49. P. 1016-1021.

9. http://www.ncbi.nlm.nih.gov/

10. Ruttner F. Biogeography and Taxonomy of Honeybees.: Springer-Verlag, Berlin, Heidelberg, 1988. $-260 \mathrm{p}$.

11. Schatz G. Mitochondria. The next 100 years // Karger Gazette. - 1994. - V. 58. - P. 1-2.

12. Wolstenholme D. R., Jeon K. W. Animal mitochondrial DNA: structure and evolution / Mitochondrial Genomes. - 1992. - Academic Press.

- San Diego. - 216 p. 